\title{
-THE SYSTEMIC LESIONS OF WHIPPLE'S DISEASE
}

\author{
BY \\ P. FARNAN \\ From St. George's Hospital, London
}

(RECEIVED FOR PUBLICATION JUNE 16, 1958)

In the 50 years since the first case report by Whipple (1907), the British contribution to the subject of "intestinal lipodystrophy" consists of five communications, namely, those of Glynn and Rosenheim (1938) and of Vaux (1943), in neither of which the condition was recognized, and the more recent reports of Avery Jones and Paulley (1949), Christie and Galton (1952), and Paulley (1952). All these papers are clinical in aspect, and due attention has been paid in them, and also in annotations in both the Lancet (1953) and the British Medical Journal (1955 and 1957), to the many bizarre features which constitute the syndrome. This, in its classical form, is a disease of insidious onset, affecting mainly male subjects of middle age. It is frequently associated with a multiple arthritis, severe steatorrhoea, and steady decline ending in death.

In contrast to this small number, there have been 28 case reports from America since 1950, of which 10 were diagnosed before death by laparotomy and mesenteric node biopsy, and five suspected on clinical grounds alone. Recognition of the disease during life has of late assumed added importance because of the emphasis on treatment in recent American articles (Jones, Benson, and Roque, 1953 ; Lepore, 1954 ; Wang, Janowitz, and Adlersberg, 1956) and also because the publication during the same period of several small series of cases (Hendrix, Black-Schaffer, Withers, and Handler, 1950 ; Russo, 1952 ; Casselman, Macrae, and Simmons, 1954 ; Puite and Tesluk, 1955) suggests that the condition may be more common than has hitherto been suspected.

\section{The Present Study}

The present paper is concerned with seven cases of the condition occurring in England: the main aetiological and clinical features of this group are summarized in Table I. The main pathological interest has always centred upon the jejunal mucosa and mesenteric lymph nodes, where the presence of macrophages containing Schiff-positive material is invariable, and essential for
TABLE I

THE AETIOLOGY AND SYMPTOMS OF SEVEN CASES OF WHIPPLE'S DISEASE

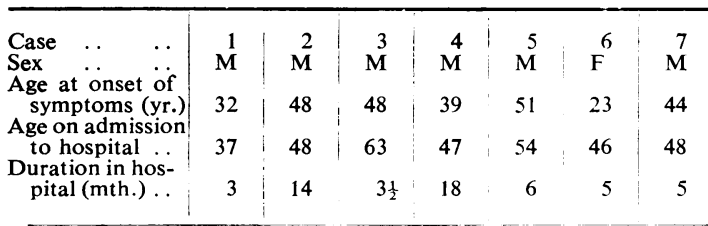

\begin{tabular}{|c|c|c|c|c|c|}
\hline \multicolumn{3}{|c|}{ The Prodromal Period } & \multicolumn{3}{|c|}{ Period in Hospital } \\
\hline \multirow{2}{*}{ Symptoms } & \multicolumn{2}{|c|}{$\begin{array}{l}\text { Average } \\
\text { Duration }\end{array}$} & \multirow{2}{*}{\multicolumn{2}{|c|}{ Clinical Features }} & \multirow{2}{*}{$\begin{array}{l}\text { No. of } \\
\text { Cases }\end{array}$} \\
\hline & $\begin{array}{l}0-5 \\
\mathrm{yr} .\end{array}$ & $\begin{array}{c}5-10 \\
\text { yr. }\end{array}$ & & & \\
\hline 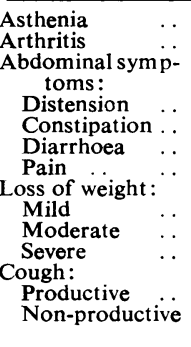 & $\begin{array}{l}2 \\
3 \\
1 \\
3\end{array}$ & $\begin{array}{c}1 \\
N_{i l} \\
1 \\
1\end{array}$ & $\begin{array}{l}\text { Asthenia . . } \\
\text { Emaciation } \\
\text { Hypotension } \\
\text { Pigmentation } \\
\text { Abdominal signs: } \\
\text { Distension } \\
\text { Mass . } \\
\text { Pain or tenderne } \\
\text { Ankle oedema } \\
\text { Lymphadenopathy } \\
\text { Localized } \\
\text { Generalized } \\
\text { Purpura .. } \\
\text { Fever . } \\
\text { Heart murmurs } \\
\text { "Sudden" death }\end{array}$ & $\begin{array}{l}\ldots \\
\cdots \\
\cdots \\
\ldots \\
\cdots \\
\text { ess } \\
\ldots \\
y \\
\cdots \\
\cdots \\
\cdots \\
\cdots\end{array}$ & $\begin{array}{l}4 \\
5 \\
6 \\
5 \\
6 \\
6 \\
1 \\
3 \\
3 \\
\\
2 \\
3 \\
1 \\
2 \\
1 \\
1\end{array}$ \\
\hline
\end{tabular}

diagnosis (Figs. 1, 2a, and 2b). In addition, however, more widespread lesions are usually present, as can be seen from Table II, which summarizes the necropsy findings in the 60 adequately documented cases previously reported, and the present series.

Thus, fluid and adhesions in the serous cavities are common, as are thickening and "sugar-icing" of the splenic and liver capsules. Whereas mesenteric adenopathy is invariable, lymph node enlargement elsewhere is frequently recorded, particularly in the thoracic and para-aortic regions, as well as at the periphery, where localized or generalized adenopathy is present in over half the published case reports. As part of the general investigation of the condition, peripheral lymphnode biopsy has been performed on several occasions, and a number of observers (Upton, 1952 ; Russo, Case 2, 1952 ; Fisher and Whitman, 


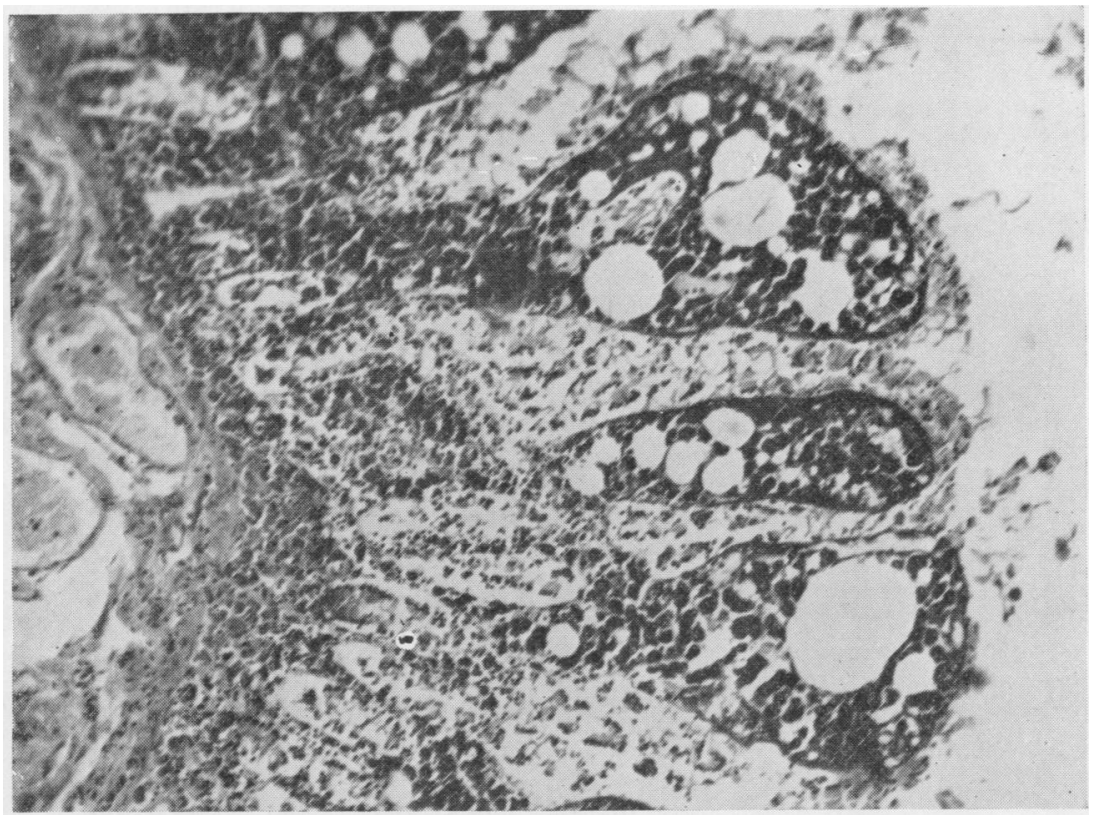

FIG. 1. Section of the jejunal mucosa $(\times 75)$ shows the club-shaped villi containing fat-filled spaces which are surrounded by large numbers of macrophages which are filled with densely staining Schiffpositive granules.

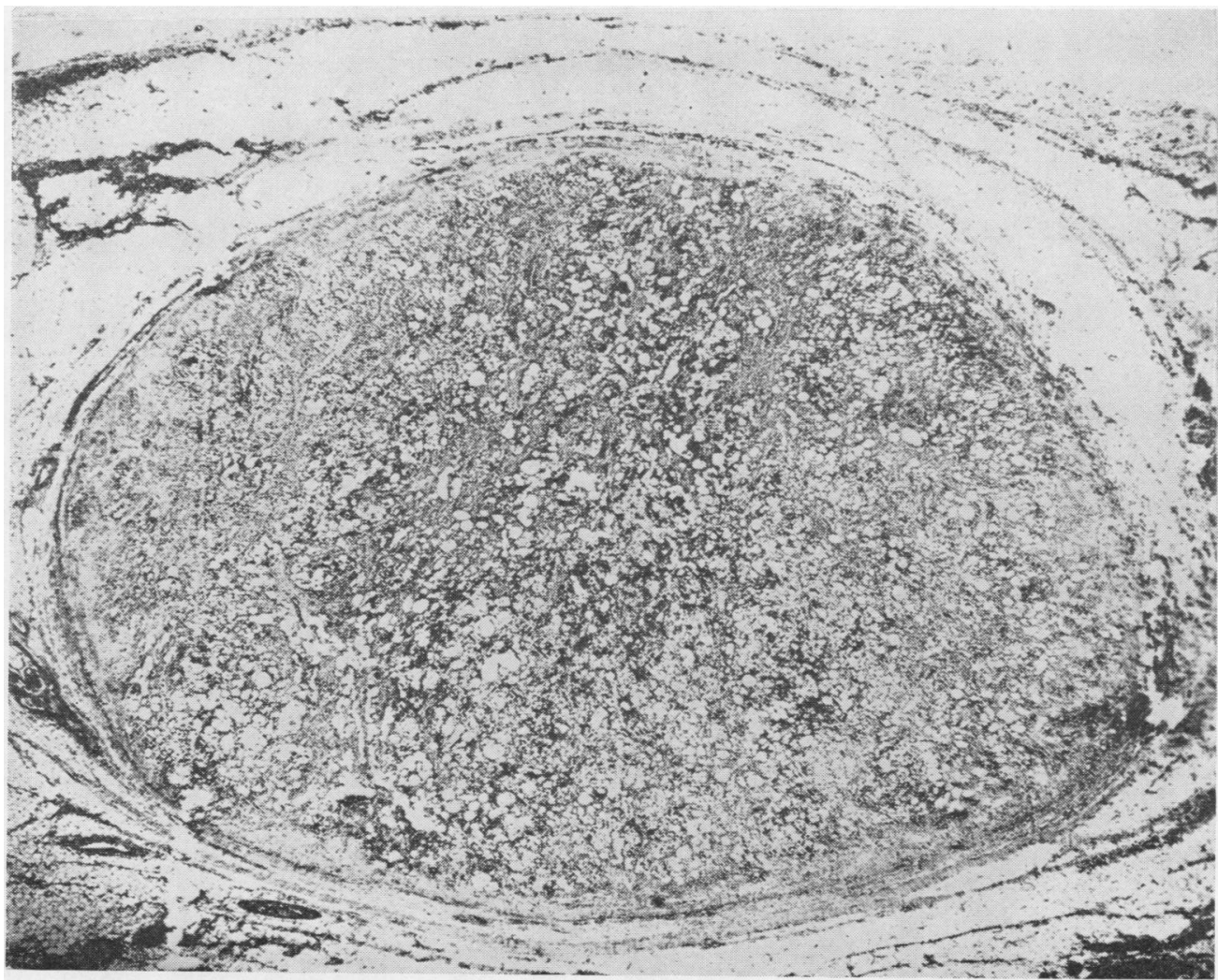

FIG. $2 a$.-Section of a mesenteric lymph-node $(\times 16)$ shows the characteristic " honeycomb" appearance, the spaces containing many large fat droplets. 

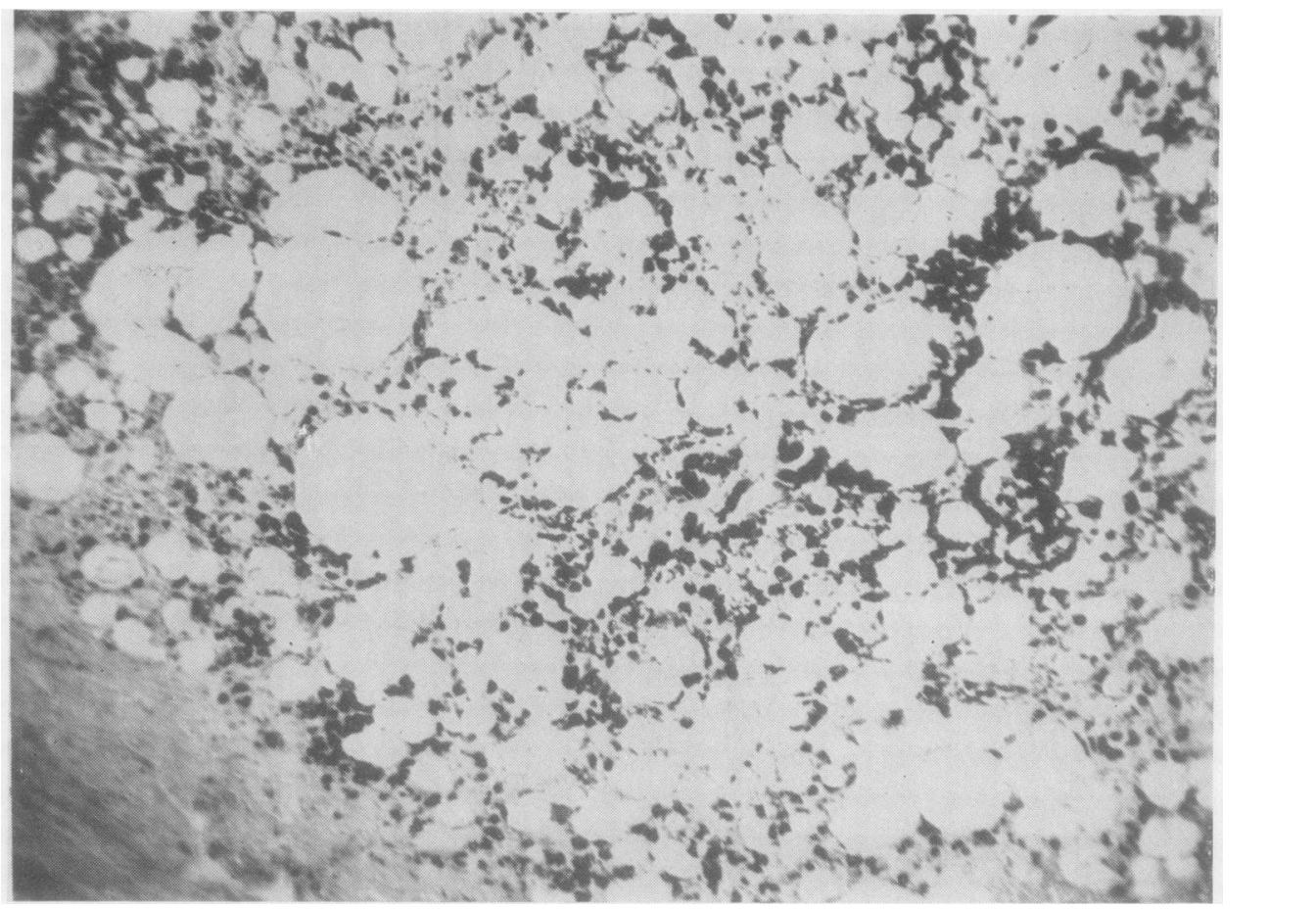

FIG. 2b.-A high-power view $(75)$ shows the fat spaces interspersed with dense aggregations of Schiff-positive macrophages.

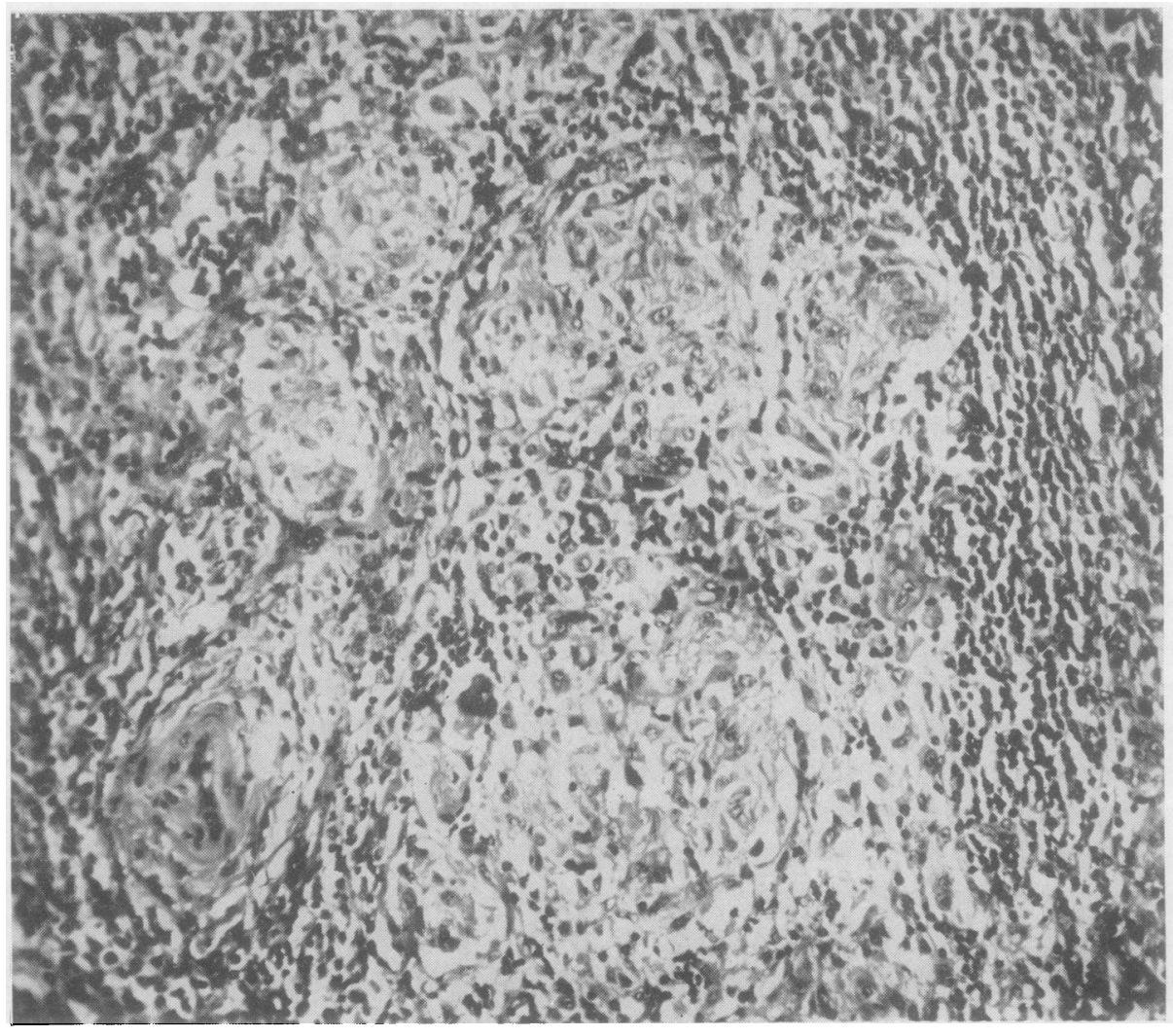

FIG. 3.-Section of a peripheral lymph node shows an indefinite "sarcoid-like" lesion (Case 5) composed of epithelioid and giant-cell aggregations, with a few Schiff-positive macrophages arranged singly. 
TABLE II

MAIN GROSS AND MICROSCOPIC FINDINGS AT NECROPSY IN 67 CASES OF WHIPPLE'S DISEASE

\begin{tabular}{|c|c|c|c|}
\hline Finding & $\begin{array}{c}60 \\
\text { Reported } \\
\text { Cases }\end{array}$ & $\begin{array}{l}\text { Present } \\
\text { Series of } \\
7 \text { Cases }\end{array}$ & $\%$ \\
\hline $\begin{array}{l}\text { Mesenteric adenopathy (with Schiff- } \\
\text { positive macrophages) } \\
\text { Similar macrophages in jejunal mucosa } \\
\text { Marked loss of subcutaneous fat } \\
\text { Skin pigmentation } \ldots \\
\text { Potechial haemorrhages in skin }\end{array}$ & $\begin{array}{l}56 \\
54 \\
50 \\
36 \\
24\end{array}$ & $\begin{array}{l}7 \\
7 \\
6 \\
5 \\
3\end{array}$ & $\begin{array}{l}95 \\
92 \\
84 \\
62 \\
41\end{array}$ \\
\hline 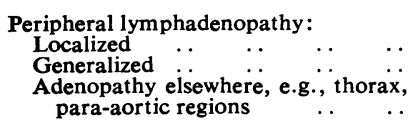 & $\begin{array}{r}16 \\
7 \\
18\end{array}$ & $\begin{array}{l}2 \\
3 \\
6\end{array}$ & $\begin{array}{l}27 \\
15 \\
36\end{array}$ \\
\hline $\begin{array}{l}\begin{array}{l}\text { Involvement of serous cavities: } \\
\text { Pericardial fluid } \quad .\end{array} \quad \ldots \quad \ldots \\
\text { adhesions } \\
\text { Subepicardial macrophages (Schiff- }\end{array}$ & $\begin{array}{r}6 \\
21\end{array}$ & $\begin{array}{l}2 \\
6\end{array}$ & $\begin{array}{l}12 \\
40\end{array}$ \\
\hline 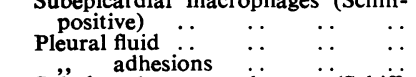 & $\begin{array}{r}1 \\
10 \\
17\end{array}$ & $\begin{array}{l}3 \\
\mathbf{3}\end{array}$ & $\begin{array}{l}20 \\
30\end{array}$ \\
\hline $\begin{array}{cccc}\text { Subpleural } & \text { macrophages } & & \text { (Schiff- } \\
\text { positive) } \\
\text { Peritoneal fluid } & \cdots & \ldots & \ldots \\
,, \quad \text { adhesions } & & \cdots & \ldots\end{array}$ & $\begin{array}{r}1 \\
10 \\
7\end{array}$ & $\begin{array}{l}3 \\
1\end{array}$ & $\begin{array}{l}20 \\
12\end{array}$ \\
\hline 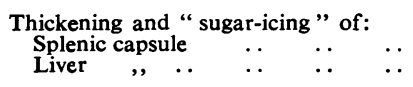 & $\begin{array}{r}13 \\
9\end{array}$ & $\begin{array}{l}3 \\
3\end{array}$ & $\begin{array}{l}24 \\
18\end{array}$ \\
\hline 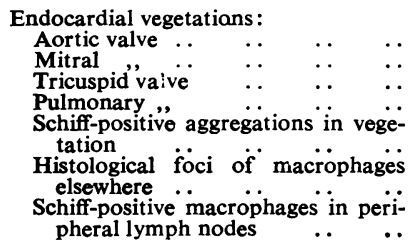 & $\begin{array}{c}8 \\
8 \\
7 \\
\text { Nil }\end{array}$ & $\begin{array}{l}2 \\
2 \\
2 \\
1 \\
1 \\
1\end{array}$ & $\begin{array}{l}15 \\
15 \\
14\end{array}$ \\
\hline
\end{tabular}

1954) have recorded in very similar phraseology the finding of an "indefinite sarcoid-like picture," a presenting feature which was also found in Case 5 of the present series (Fig. 3).

The observation by Fisher and Whitman (1954) that the presenting histological picture was "too non-specific to be of diagnostic value " was to be later refuted by Puite and Tesluk (1955), who found small clusters of the characteristic Schiffpositive macrophages in the substance of the sarcoid-like follicles. To explain this finding, which was also confirmed in Case 5 of the present series (Fig. 3), these authors postulated that " some of the material must travel by way of the blood stream"; and there is additional support, both clinical and pathological, for the idea that the material is disseminated periodically by this route.

Thus, in Case 1 of the present series, endocardial vegetations were responsible for destruction of the aortic valve and the late development of classical aortic regurgitation; and vegetations, affecting equally the aortic, mitral, and tricuspid valves, are present in over one-third of the case reports. Except in the case of Upton (1952), these vegeta- tions do not appear previously to have been examined microscopically, but in Case 7 of the present series small aggregations of Schiffpositive material were clearly demonstrable in the substance of the vegetation (Figs. 5 and 6), indicating not only spread by the blood stream but the possibility that this material had caused a predisposing valvulitis.

In similar manner, it is probable that the widespread lesions represent an inflammatory or "allergic" reaction to small amounts of the material, an idea which would be in keeping with the features of the prodromal period, which is characterized by acute exacerbations of protean symptoms alternating with long periods of freedom. The characteristic macrophages have been demonstrated in widespread sites-liver, spleen, retroperitoneal tissues-by Upton (1952) and also in Case 5 of the present series, where they were observed in the subpleural and subepicardial regions as well as in the retroperitoneal tissues. Careful search is necessary to demonstrate them, and they may be present more frequently than suspected.

TABLE III

MAIN HISTOCHEMICAL FINDINGS IN MESENTERIC LYMPH NODES AND JEJUNAL MUCOSA IN WHIPPLE'S DISEASE

\begin{tabular}{|c|c|c|}
\hline $\begin{array}{l}\text { Substance } \\
\text { Tested }\end{array}$ & Method & Result \\
\hline $\begin{array}{l}\text { Fat stains } \\
\text { (frozen } \\
\text { sections) }\end{array}$ & $\begin{array}{l}\text { Oil red O } \\
\text { Sudan black B } \\
\text { Sudan III and IV } \\
\text { Nile blue sulphate } \\
\text { Schultz's method for choles- } \\
\text { terol }\end{array}$ & $\begin{array}{l}\text { Positive } \\
\text {,", } \\
\text {," } \\
\text {," }\end{array}$ \\
\hline Carbohydrate & $\begin{array}{l}\text { Periodic-acid-Schiff (Hotch- } \\
\text { kiss, 1948) } \\
\text { (a) P.A.S. after acetylation; } \\
\text { (b) after subsequent } \\
\text { deacetylation (McManus } \\
\text { and Cason, 1950) } \\
\text { P.A.S. after diastase } \\
\text { " ", hyaluronidase }\end{array}$ & $\begin{array}{l}\text { Positive } \\
\text { (a) Positive reaction } \\
\text { (Schiff neg.) } \\
\text { (b) Positive reaction } \\
\text { (Schiff positive) } \\
\text { No change } \\
\text { Some diminution in } \\
\text { colour intensity }\end{array}$ \\
\hline Protein & $\begin{array}{l}\text { Xanthoprotein reaction (Serra, } \\
\text { 1946) } \\
\text { Millon reaction (Pearse, 1953) } \\
\text { Sakaguchi reaction (Baker's } \\
\text { modification) }\end{array}$ & $\begin{array}{l}\text { Negative (tryp:o- } \\
\text { phane) } \\
\text { Negative (tyrosine) } \\
\text { Moderately positive } \\
\text { (arginine) }\end{array}$ \\
\hline Miscellaneous & $\begin{array}{l}\text { Metachromatic stains: } \\
1 \% \text { Toluidine blue } \\
1 \% \text { Thionin } \\
1 \% \text { Methyl violet } \\
\text { Dialysed iron (Hale, 1946) } \\
\text { Methylene blue extinction } \\
\text { (range } p \mathrm{H} \text { 1.9-9.5) } \\
\text { Alcian blue (mucin) } \\
\text { Mucihaematin (Laskey, 1950) } \\
\text { Perls's reaction (Fe) }\end{array}$ & $\begin{array}{l}\text { Positive } \\
\quad,, \\
\text {," } \\
\text { Positive to level } p \mathrm{H} \\
3 \cdot 6 \\
\text { Positive } \\
\text { Negative } \\
\quad,,\end{array}$ \\
\hline
\end{tabular}

The stains for fat refer only to the enlarged cystic spaces in the mucosa and mesenteric lymph nodes. 


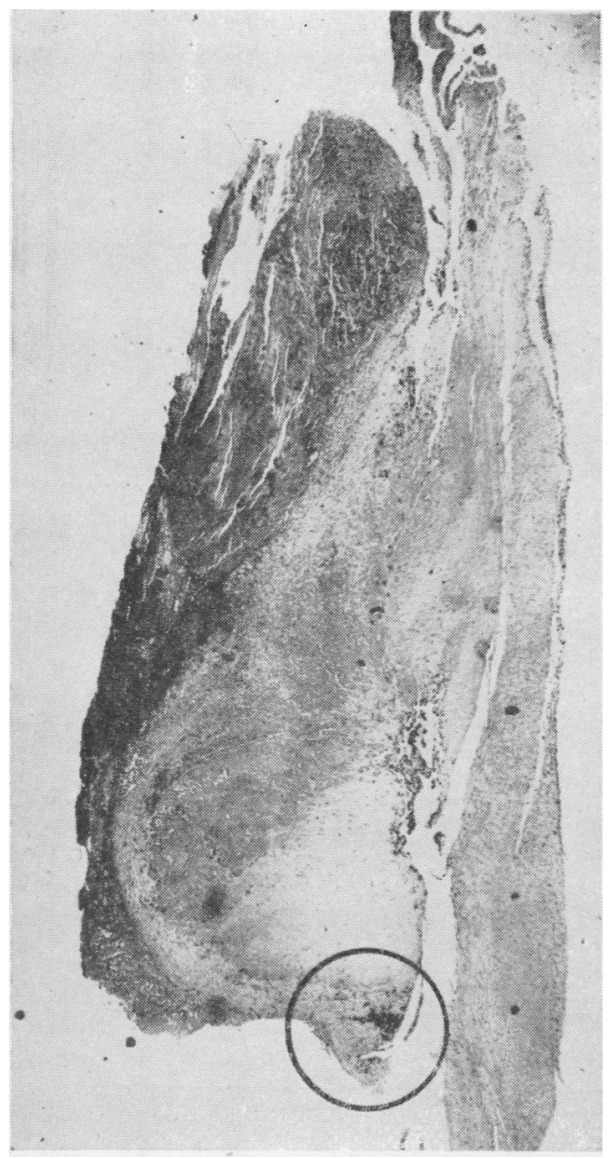

FIG. 4

FIG. 4.- $(\times 30)$. A small vegetation from the pulmonary valve (Case 7) shows the incorporation of small groups of Schiffpositive macrophages.

FIG. 5.-A high-power $(\times 280)$ view of the area showing Schiff-positive granules.
Histochemical and Experimental Considerations

Since the investigations of Black-Schaffer (1949), attention has been increasingly focused upon the macrophage which is characteristic of the disease. Its properties have been studied by several authors (Upton, 1952 ; Fisher and Whitman, 1954) and its histochemical characteristics have been subsequently investigated most carefully by Casselman et al. (1954). The main investigations on this material in the present study are summarized in Table III, from which the same general conclusion is drawn as in previous studies, that the material is a mucopolysaccharide. The main differences from the findings of Casselman et al. (1954) were that the tests for protein were only very slightly positive ; that the methylene blue extinction test was

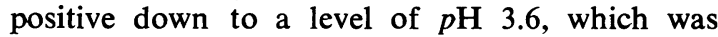

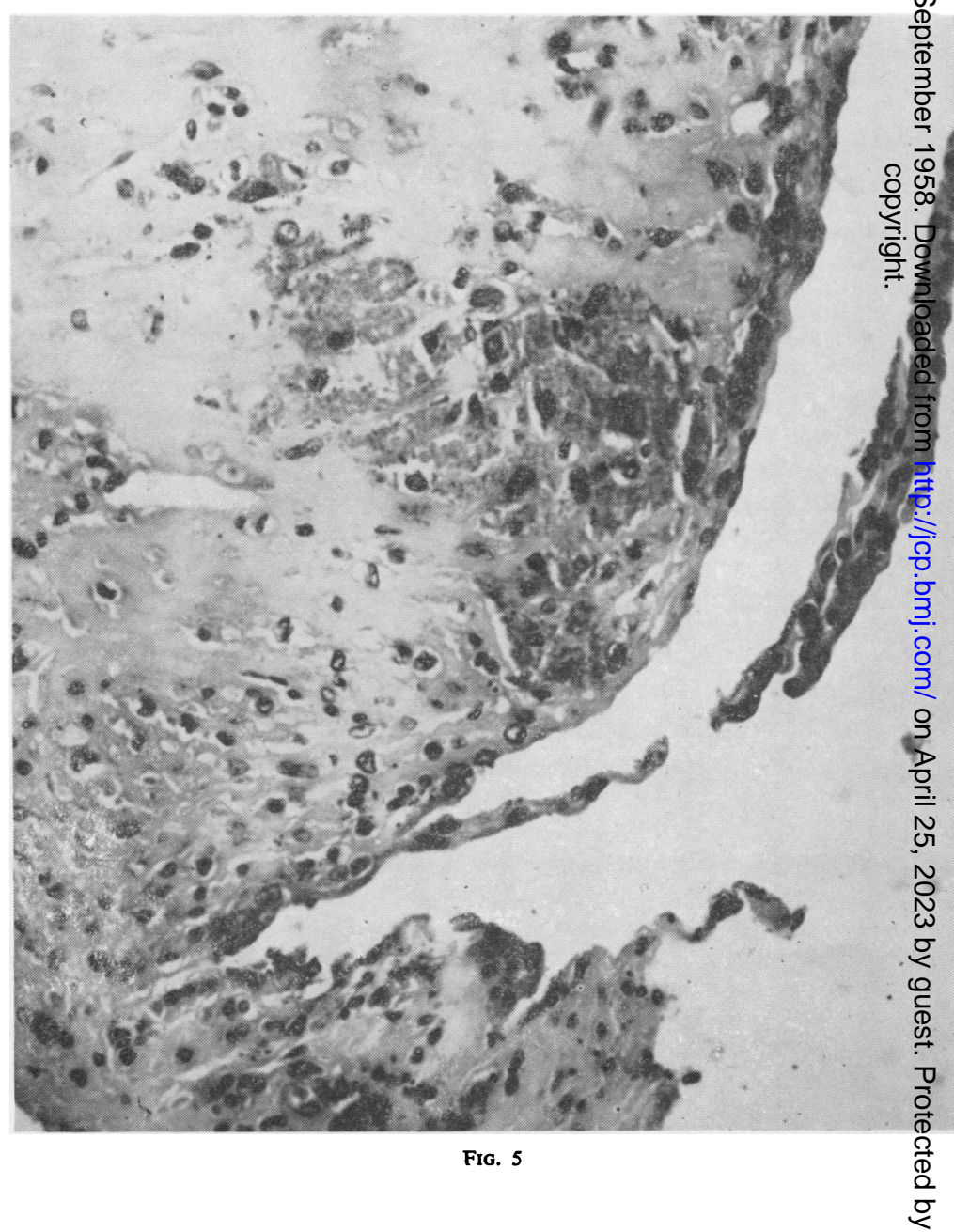


also reported by Jones et al. (quoted by Casselman); and that some impression appeared to be made upon the material after incubation with hyaluronidase.

Although the stored material has been characterized on several occasions, there has been no attempt to reproduce the characteristic histiocyte in the experimental animal, or to study the systemic effects of circulating mucopolysaccharide. The only authors whose experimental observations are quoted in connexion with Whipple's disease are Hass (1938) and Stryker (1941), the former having studied the tissue reactions to natural oils and their derivatives, while the latter was concerned with the tracing and disposal of large quantities of liquid paraffin after ingestion. Both authors were working at a time when the basis of the condition was thought to be a disturbance of fat metabolism, but the lesions observed bear no more than a superficial resemblance to the characteristic appearances of Whipple's disease.

With the advent and use of specially refined "dextran," the effects of circulating polysaccharides have been investigated by a number of authors (Goldenberg, Crane, and Popper, 1947 ; Engstrand and Åberg, 1950; Persson, 1952; Friberg, Graf, and Åberg, 1953 ; and Wolman, 1956), but an examination of the tissue reactions to the mucopolysaccharide stored in Whipple's disease must await its specific identification. However, due to the work of Meyer (1938) and Stacey (1943, 1946), a number of substitutes are available. The former included only hexosaminecontaining compounds, but Stacey included many other complex carbohydrates, which he divided into four main groups, viz., (a) containing hexosamine and uronic acid; $(b)$ containing no uronic acid ; $(c)$ containing no hexosamine ; and $(d)$ without hexosamine or uronic acid residues. The first of these groups includes such substances as hyaluronic acid, heparin, chrondroitin sulphate and mucoitin sulphate (from gastric mucin), and since this latter material was readily available it was chosen for further experimental observation.

\section{Materials and Methods}

The pilot experiments were carried out on five rabbits and six mice: the solution used for injection in all instances was a $2 \%$ solution of hog's gastric mucin (National Biochemical Corporation, Cleveland, Ohio) in sterile saline.

The mice were used only for intraperitoneal investigation. One millilitre of the solution was injected into the peritoneal cavity of three mice and examinations made after two, four, and six days. A similar routine was followed after an initial injection of $2 \mathrm{ml}$. of liquid paraffin, which was designed to promote an active inflammatory exudate. Intraperitoneal injections of $2 \mathrm{ml}$. of the solution were also performed in one rabbit, at intervals of three days, for periods of two and three weeks.

Two millilitres of the solution were injected intradermally into the abdominal wall of one rabbit; the surrounding areas were examined microscopically at intervals of three and six days, and the site of injection was itself examined latterly.

Intravenous injections of $10 \mathrm{ml}$. of the solution were given in three rabbits daily over periods of two days, one week, and two weeks, and similar amounts were injected on alternate days over a period of three weeks.

From the animal subjected to intraperitoneal injection, the peritoneum and abdominal lymph nodes were examined microscopically. The skin and injection site were examined in the rabbit subjected to intradermal injection, and from those in which the solution had been given intravenously the heart and pericardium, the lungs and pleurae, liver, spleen, kidneys, peritoneum, and lymph nodes in both thorax and abdomen were examined histologically.

All the material was stained by haematoxylin and eosin, and the Hotchkiss modification of the periodicacid-Schiff stain (McManus, 1946). The liver parenchyma was in addition stained by Best's carmine method.

\section{Results}

In spite of the large doses of material used, the animals' health remained good throughout the experiments, with the exception of early loss of appetite and malaise, which did not persist. The injected material stained adequately with the Schiff stain.

The material injected intraperitoneally in the mice excited little inflammatory reaction: after liquid paraffin, mononuclear cells and polymorphonuclear leucocytes were observed in moderate numbers, but there was no histological evidence that the mucin was being phagocytosed. In the rabbits, there was no loss of translucency or peritoneal exudate. The material was readily eliminated, and the abdominal glands were enlarged and showed small amounts of the material in the cortical sinuses.

The initial result of the intradermal injections was an acute inflammatory reaction in the neighbourhood of the material. Phagocytosis occurred readily, several large mononuclear cells in the neighbourhood showing a vacuolated cytoplasm, which was Schiff-positive. The injection site itself later became heavily infiltrated by chronic inflammatory cells.

The effects of intravenous administration were observed in all organs. After two injections on successive days, the most marked changes were 


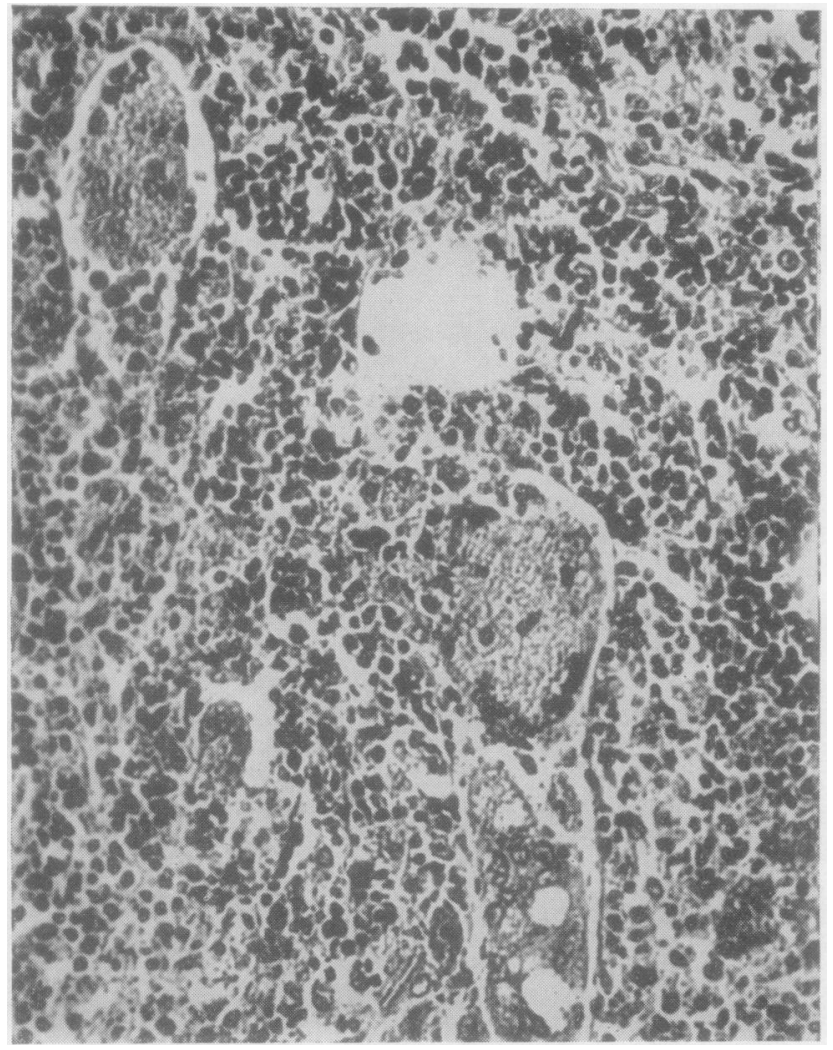

FIG. 6.-The rabbit spleen $(\times 200)$ after injection of large amounts of intravenous mucopolysaccharide shows reticulum-cell hyperplasia forming giantcells, and containing a foamy cytoplasm which is moderately Schiffpositive.

observed in the kidneys which were hyperaemic, and showed swelling of the glomeruli and epithelium of the proximal convoluted tubules. In the liver there was moderate periportal acute inflammatory infiltration, and the Kupffer cells were swollen and vacuolated, containing droplets of Schiff-positive material (Fig. 7).

Observations on those animals injected for periods of one to three weeks differed only in degree. The lymph nodes in both thorax and abdomen were enlarged: moderate amounts of Schiff-positive material were present, apparently lying free in the sinuses. The liver showed droplets of Schiff-positive material in both the Kupffer cells and the parenchymal cells. In the kidneys there were small amounts of the material in the capsular spaces and in the tubular epithelium, but in the animals subjected to intermittent dosage there was little evidence of accumulation of the material.

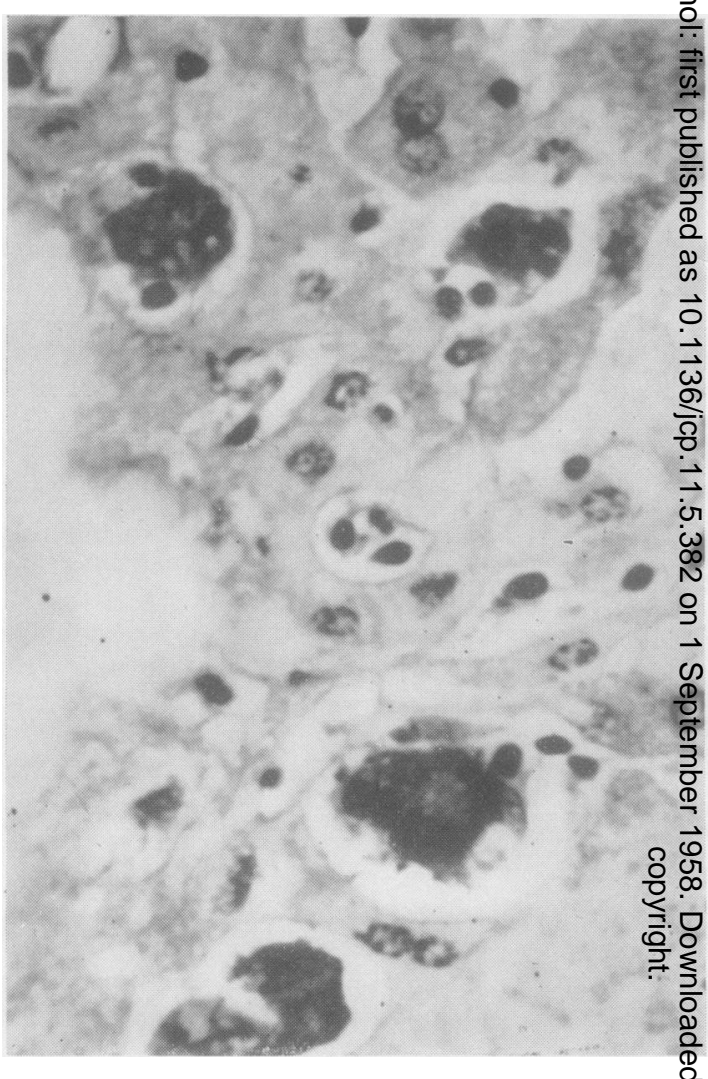

FIG. 7.-The rabbit liver $(\times 500)$ shows similar hyperplasia of the Kupffer cells, which are incorporating large amounts of deefy staining Schiff-positive material. Smaller droplets, resistant $\$ 0$ diastase, can be seen in the parenchymal cells.

The lungs showed thickening of the pulmonary interstitial tissue, which was infiltrated by mononuclears and granulocytes, and there was considerable hyperplasia of the pulmonary lymphoid tissue. The spleen showed marked hyperplasia of the Malpighian corpuscles in the animal subjected to the longest administration, and the pulp contained large numbers of multinucleated giant cells with a vacuolated cytoplasm (Fig. 6) which was moderately Schiff-positive. The appearances resembled those described by Hueper (1942a and 1942 b) in connexion with the response to pectin.

In one of the final experiments, injections were stopped four days before examination and a marked diminution was observed in the amount of Schiff-positive material in the liver parenchyma and reticulo-endothelial system.

Examination of the serous membranespleura, pericardium, and peritoneum-failed to show evidence of inflammation, or aggregation of the mucus itself. 
These results parallel very closely observations made previously by several authors on the tracing, storage, and disposal of polysaccharide material. The experiments are of interest in demonstrating the ability of the experimental animal to dispose of large quantities of mucopolysaccharide material, but in the context of the present study this attempt to explain the inflammation of the serous membranes was unsuccessful.

Another objective, however, to determine if it were possible to demonstrate the phagocytosis of circulating mucopolysaccharide, was successful. The giant cells seen in the spleen resemble the macrophages of Whipple's disease only superficially. But these appearances may have been modified by such factors as the duration of the experiment, dosage used, the organ involved, and the mode of administration. Further study along the same lines must clearly await the isolation and chemical identification of the material stored in this condition.

\section{Discussion}

After Black-Schaffer (1949) had demonstrated the character of the material in the macrophages, interest as to the pathogenesis of Whipple's disease was centred upon the steatorrhoea which is frequently a dominant feature of the condition as seen in hospital. Thus the idea of an "abnormal" or "abnormally split" fat in the intestine, with inflammatory obstruction of the mesenteric lymphatics, was postulated in various guises over a long period (Whipple, 1907 ; Gaertner, 1938 ; Korsch, 1938 ; Escudero, Mosto, and Landabure, 1945 ; Reveno, 1950). An abnormal "excretion" of fat directly into the intestine or mesenteric lymphatics had been suggested to explain the steatorrhoea by two groups of authors (Reinhart and Wilson, 1939 ; Sailer and McGann, 1942).

The many features of the fully developed picture can be explained on the basis of a wide-range "malabsorption" defect, but the advocates of the obstructive theory have found difficulty in explaining the observation of two authors (Whipple, 1907; Sailer and McGann, 1942), which was confirmed in Case 1 of the present series, that the thoracic duct has been patent at necropsy. The possibility does exist, however, that the site of obstruction lies in the mucosa itself: probably the most constant observation at necropsy is the finding of large quantities of Schiff-positive material in the jejunal villi, which are themselves grossly thickened by the presence, not only of this material, but also by large, circular fat vacuoles.
The same aggregations may be responsible for the constant finding of occult blood in the stools and hypochromic anaemia, by initiating constant slight haemorrhage into the lumen of the intestine, and also for the appearances in the mesenteric lymph nodes by causing a partial degree of obstruction at that site.

While most students of the condition are in agreement upon the general character of this material, its source has never been determined. A number of observers (Black-Schaffer, 1949 ; Puite and Tesluk, 1955) regard the fundamental abnormality as being in the mucus secretion in the upper jejunum. It is noteworthy, however, that in all material examined in the present investigation, combined alcian blue and periodic-acidSchiff-staining shows what is apparently normal activity by the secreting epithelium, independent of the presence of the Schiff-positive granules which are quite sharply confined to the lamina propria of the mucosa and the underlying lacteals. This observation, together with the fact that incubation with hyaluronidase does appear to have some impression upon the material, suggests the possibility that the fundamental defect may lie in an alteration of the mucopolysaccharide ground-substance in this region. The idea of a genetic predisposition is strongly suggested by the constant age of onset, its great predominance in the male, and the fact that it has once been reported in brothers (Puite and Tesluk, 1955).

In conclusion, despite the absence of experimental confirmation in this work, the most likely explanation of the exacerbations of prodromal symptoms and the lesions in the endocardium and serous membranes is that they represent an inflammatory response to small amounts of the material in the circulation over a considerable period of time.

\section{Summary}

There is some evidence that the fundamental defect in Whipple's disease may be an alteration in the mucopolysaccharide ground-substance of the jejunal mucosa. Another case is recorded in which the characteristic macrophages have been found in widespread sites, and also incorporated in endocardial vegetations.

These findings, together with the character of the prodromal symptoms, may indicate an intermittent systemic dissemination of the Schiff-positive materials, and an attempt has been made to study the systemic effects of a circulating mucopolysaccharide in the experimental animal.

Whilst the finding of the characteristic Schiffpositive macrophages in the mesenteric lymph 
nodes and jejunal mucosa is invariable and essential for diagnosis, the occurrence of these macrophages in peripheral lymph nodes, already noted, is confirmed. In this connexion, an indefinite "sarcoid-like" picture has been found sufficiently frequently to be suggestive in the correct context.

The severe steatorrhoea and "malabsorption" defects which often dominate the patients' final period in hospital are probably the result of excessive formation of the material causing obstruction at the mucosal site.

My thanks are due to several clinicians and pathologists who have allowed me to examine their material, or directed attention to possible sources, and in particular to Professor T. Crawford for advice and criticism and for undertaking all the photography included in the paper.

The paper is part of a report awarded a registrars' research prize (1957) by the South-West Metropolitan Regional Hospital Board.

\section{REFERENCES}

Black-Schaffer, B. (1949). Proc. Soc. exp. Biol. (N.Y.), 72, 225. British Medic a! Journal (1955). Annot. "Whipple's Disease," 2, 191. Casselman, w. G. B., Macrae, A. I., and Simmons, E. H.' (1954). J. Path. Bact., 68, 67.

Christie, A. C., and Galton, D. A. G. (1952). Ibid., 64, 351

Engstrand, L., and A berg, B. (1950). Lancet, 1, 1071.
Escudero, P., Mosto, D., and Landabure, P. B. (1945). Dia méd., 17,915 .

Fisher, E. R., and Whitman, J. (1954). Cleveland Clin.Quart., 21, 213. Friberg, U., Graf, W., and Áberg, B. (1953). Acta pharmacol.(Kbh.), $9,220$.

Gaertner, K. (1938). Frankfurt. Z. Path. 52, 529.

Glynn, L. E., and Rosenheim, M. L. (1938). J. Path. Bact., 47, 285. Goldenberg, M., Crane, R. D., and Popper, H. (1947). Amer. J. clin. Path., 17, 939.

Hale, C. W. (1946). Nature (Lond.), 157, 802.

Hass, G. M. (1938). Arch. Path. (Chicago), 26, 1196.

Hendrix, J. P., Black-Schaffer, B., Withers, R. W., and Handler, P. (1950). Arch. intern. Med., 85, 91.

Hotchkiss, R. D. (1948). Arch. Biochem., 16, 131.

Hueper, W. C. (1942a). Amer. J. Path., 18, 895.

- (1942b). Arch. Path. (Chicago), 33, 267.

Jones, C. M., Benson, J. A., and Roque, A. L. (1953). New Engl. J. Med., 248, 665.

Jones, F. Avery, and Paulley, J. W. (1949). Lancet, 1, 214.

Korsch, J. H. (1938). Zbl. allg. Path. path. Anat., 71, 337.

Lancet (1953). Annot. " Whipple's Disease," 2, 79.

Laskey, A. (1950). Stain. Tech., 25, 33.

Lepore, M. J. (1954). Amer. J. Med., 17, 160

McManus, J. F. A. (1946). Nature (Lond.), 158, 202.

and Cason, J. E. (1950). J. exp. Med., 91, 651.

Paulley, J. W. (1952). Gastroenterology, 22, 128

Paulley, J. W. (1952). Gastroenterology, 22, 128 .

Pearse, A. G. E. (1953). Histochemistry, Churchill, Lond
Persson, B. H. (1952). Acta Soc. Med. upsalien, 57, 411.

Puite, R. H., and Tesluk, H. (1955). Amer. J. Med., 19, 383

Reveno, W.'S. (1950). New Engl. J. Med., 243, 216.

Reinhart, H. L., and Wilson, S. J. (1939). Amer. J. Path., 15, 483.

Russo, F. R. (1952). Arch. intern. Med., 89, 600.

Sailer, S., and McGann, R. J. (1942). Amer. J. dig. Dis., 9 .55.

Serra, J. A. (1946). Stain Technol., 21, 5.

Stacey, M. (1943). Chem. and Ind., 62, 110.

- (1946). Advanc. Carbohyd. Chem., 2, 161.

Stryker, W. A. (1941). Arch. Path. (Chicago), 31, 670

Upton A. C. (1952), Amer. J. clin. Path.,22, 755.

Vaux, D. M. (1943). J. Path. Bact., 55, 93.

Wang, C. I., Janowitz, H. D., and Adlersberg, enterology, 30, 475.

Whipple, G. H. (1907). Johns Hopk. Hosp. Bull., 18, 382.
Wolman, M. (1956). A.M.A. Arch. Path., 62, 149. 